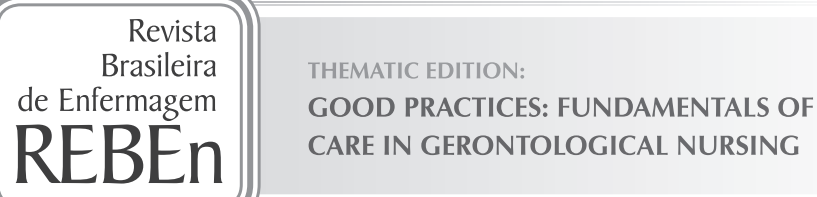

\title{
Transcendence, historicity and temporality of being elderly: nursing reflection-using Heidegger
}

\author{
Trascendencia, historicidad y temporalidad del ser adulto mayor: reflexión enfermera en Heidegger
}

Transcendência, historicidade e temporalidade do ser idoso: reflexão de enfermagem sob a ótica de Heidegger

\section{Raúl Fernando Guerrero-Castañeda', Marta Lenise do Prado", Silvana Silveira Kempfer", Maria Guadalupe Ojeda Vargas'}

\author{
' Universidad de Guanajuato, Campus Celaya-Salvatierra, Division of Health Sciences and Engineering. \\ Celaya, Guanajuato, Mexico. \\ "Universidade Federal de Santa Catarina, Nursing Department. Florianópolis, Santa Catarina, Brazil.
}

\section{How to cite this article:}

Guerrero-Castañeda RF, Prado ML, Kempfer SS, Ojeda Vargas MG. Transcendence, historicity and temporality of being elderly: nursing reflection-using heidegger. Rev Bras Enferm [Internet]. 2017;70(4):891-5. [Thematic Edition "Good Practices: Fundamentals of care in Gerontological Nursing"] DOI: http://dx.doi.org/10.1590/0034-7167-2016-0275

Submission: 06-28-2016

Approval: 01-08-2017

\begin{abstract}
The objective is to reflect on historicity and temporality as paths for the transcendence of being elderly, based on the phenomenological concepts of Martin Heiddeger. A review of the concepts of transcendence, historicity and temporality was carried out in the work of Martín Heidegger, integrating them in the perspective of nursing for the elderly. The transcendence of the elderly adult is feasible by accessing the temporality of self in the path of its historicity to arrive at the understanding of itself that he has achieved: transcending, which is but a process of the Being itself. Being is time in itself existing in the world, existence given by the encounter of the past (to have been), present and future (becoming), the same encounter that determines the historicity of the Being. The encounter has been consummated and the Being is transcendence, with the understanding of the Being itself as a supreme point.
\end{abstract}

Descriptors: Elderly; Philosophy; Nursing; Aging; Hermeneutics.

\section{RESUMEN}

El objetivo es reflexionar en la historicidad y temporalidad como caminos para la trascendencia del ser adulto mayor, basado en los conceptos fenomenológicos de Martín Heiddeger. Se llevó a cabo una revisión de los conceptos de trascendencia, historicidad y temporalidad en la obra de Martín Heidegger, realizando su integración en la perspectiva de enfermería al adulto mayor. La trascendencia del ser adulto mayor es factible accediendo a la temporalidad del mismo en el camino de su historicidad para llegar a la comprensión de sí a la que ha llegado: trascendiendo, que no es sino un proceso del mismo ser. El ser es el tiempo en sí mismo existiendo en el mundo, existencia dada por el encuentro del pasado (haber sido), presente y futuro (devenir), mismo encuentro que determina la historicidad del ser. El encuentro se ha consumado y el ser es trascendencia, como punto supremo la comprensión del ser mismo.

Descriptores: Anciano; Filosofía; Enfermería; Envejecimiento; Hermenéutica.

\section{RESUMO}

O objetivo é refletir acerca da historicidade e da temporalidade como caminhos para a transcendência do ser idoso, com base nos conceitos fenomenológicos de Martin Heiddeger. Foi realizada uma revisão dos conceitos de transcendência, historicidade e temporalidade no trabalho de Martín Heidegger, integrando-os na perspectiva da enfermagem para o idoso. A transcendência do idoso é viável acessando a sua temporalidade no caminho de sua historicidade para chegar à compreensão de si mesmo: transcendendo, que é um processo do próprio Ser. O ser é o tempo em si mesmo existindo no mundo, existência dada pelo encontro do passado (ter sido), presente e futuro (porvir), o mesmo encontro que determina a historicidade do Ser. O encontro se efetiva e o Ser é transcendência, como um ponto supremo da compreensão de si mesmo.

Descritores: Idoso, Filosofia, Enfermagem, Envelhecimento, Hermenêutica. 


\section{INTRODUCTION}

The Being is the fundamental interest of Heideggerian phenomenology; this is a central point of his philosophy. Understanding phenomenology as the study of phenomena as they are shown to the Being in the world, one can collect the idea that it is the Being itself who gives meaning to its experiences throughout life. Phenomenology used in nursing has managed to understand many phenomena that are part of the care process; these phenomena are framed by lived experiences and meanings that are attributed in different contexts of life and the world, as well as in various stages, which are not separated from the Being, but belong to its very essence.

The elderly adult understood as a Being is not the exception of the study of phenomenology in nursing, since it is the Being itself in an existence that is its own. It is imperative for the nursing discipline to understand many of the phenomena that concern the elderly, as it is a subject of their care and, given the importance and increase of this population, requires even more understanding.

If we visualize this perspective we would have concepts that allow us to approach the elderly adult from this understanding and, in this way, to understand that which makes him who he is; and reaching that transcendence allows him to give meaning even to his present experiences.

The point of the Being is the central reason of Heidegger's study; it marks the beginning of a contemporary philosophy that breaks with idealistic philosophy, the scholastic point and the reason of man as separated from the world. This is because Heidegger's philosophy is based on the relationship of the subject to itself, not on a subject-object relationship.

This is the reason for Heidegger's phenomenology: the point of the Being; he points out that phenomenology is to see from within what is manifested and to declare it as it is; following with the famous phrase of his master Husserl, "To the things themselves"(1), he denotes the very point of the Being, it can only be understood from itself and through its path. Heidegger give the name Dasein or Being-There to the Being that questions its essence.

The Being-There thrown into the world is the same one that must be interested in its own essence, approaching existence with essence itself surpassing itself among the other Beings of the world. The Being constructs and relates itself to the world, because it is thrown into it.

Heideggerean phenomenon is that which is shown in the Being as an object and which does not remain hidden to itself but is conceived by the Being itself, is that to which he finds meaning and therefore, that which it has passed as a Being; this meaning is expressed through language, through discourse itself ${ }^{(1)}$.

In the course of Heidegger, which is recognized by authors as an existentialist phenomenology, it is important to emphasize that Heideggerean phenomenology does not lie in the description of the phenomenon itself, but in the understanding of the phenomenon itself by the Being. The ultimate expression of his philosophy is the point of the Being and the quest for its own essence.

Now then, what is the Being? Martin Heidegger places the Being as Being-There, showing the term Dasein, existing prior to any created concept, to all reason and to any subsequent analysis. Dasein, to Heidegger, is life itself, for it is the BeingThere; Dasein is not in the world, but "exists in the world". Literally it is said that man "is cast into the world", but its supreme conception is "the Being in the world," for he dwells in the world. Dasein is man himself, being that entity that has vision, he that is with himself and with other Beings, is one who is aware of being. The entity is presence, the entity is understood as the body part present in the world, and his consciousness is the very action of life of the Being in the world, it is the action, it is the behavior, so that when the Being is triggered it "exists". Existence is the very being of Being-There ${ }^{(1-2)}$.

\section{HISTORICITY AND TEMPORALITY AS PATHS FOR THE} TRASCENDENCE OF THE ELDERLY ADULT BEING

In this reflection, the concepts of temporality and historicity as pathways for the transcendence of the elderly adult will be analyzed. These concepts start from the reflection of those same concepts under the perspective of the phenomenological philosophy of Martin Heidegger, having it as a theoretical-philosophical reference to understand the complex phenomenon of the transcendence of the elderly adult Being. That transcendence, framed by a complete Being who has achieved throughout his experiences to combine the present with having been and becoming, so that today it sees itself as transcendent: complete, and finding meanings for its present experiences.

If, through the initial reflection, we can understand historicity as a path for the temporality of the Being and thus draw it to visualize the transcendent elderly adult, then the nursing care would have an opportunity to trace that care based on the concepts that allow them to understand them and to promote a culture of transcendence of the elderly adult Being that guides the Being to contemplate itself in this way. In such a way that an analysis of these concepts is made addressing them and focusing them on the elderly adult as a Being.

\section{TRANSCENDENCE}

Man has abandoned the sense and the search for the Being, because he has become part of the Beings and of their domination. The entity can remain static in the world, situated in that domination of that to which he himself is subjected. This has led theology, for example, and even science itself, to be totally distracted by the question of Being itself, preventing it from being achieved as Being, that is the task of Dasein ${ }^{(2)}$.

Heidegger separates the entity from the Being, but they are the same thing, only one, just as Being and world are one. The entity is what is and that "exists", and exists in quotation marks because the action that the entity performs in the world, as such, is what allows the Being to be. The entity is part of the existence of the world and with the world. The entity is the presence of the Being, and whose task is completed in Dasein. When this Being comes into intimate contact and can be discovered as it is; which constitutes its reason to be in the world that is to discover why it is in the world. It is not an immanent consciousness, it is the very reason of the Being that calls it and that allows it to have actions in the world where it is, because it is one with it. 
That Being in the world asks about its own existence, the path is the encounter with itself, it is a constant issue, not static, a continuous flow that does not culminate ${ }^{(1)}$. The human being as Dasein is factual; the facticity is the being in the world, united to the Being of the entity that gives reason to its own world, enjoys space, because it is physically in the world.

The Being-There is part of the self, the corporeity and the spiritual parts are not separated; for example, both are one in the Being. It is a set, which is achieved through the understanding of being in the world what makes it exist in space as such, denying the idea that first is the spirit and then the corporeal world: both are there since the beginning ${ }^{(1)}$.

Then the Being-There is the transcendence of the Being itself, thus starting the discussion of transcendence in Heidegger's view, framing it as an event, process, path and truth in the reason of the Being itself, which can be removed from the conception that transcendence is to ascend to the supreme. In his later works, he alluded to the fact that transcendence is discovered in him as a Being, transcendent for himself and in turn transcendent for meanings, since transcendence is the supremacy of the Being in relation to the basis of its existence. Transcendence travels in the Being, and with it and guarantees its authenticity, resulting in a human being understood by himself $f^{(3)}$.

It is necessary to emphasize on the basis of what does the Being transcend, itself being the first transcendence; based on what limits does it transcend and the relation based on what does the transcendence of the itself is found given that the Being has possibilities and the most important one is that it has the possibility of being itself, defining its very existence on the basis of it ${ }^{(4)}$.

In this case, the elderly adult is set as Being, he goes through a process of physical, psychological, social, labor, family changes that are presented to him (he is in the world); these changes are not far from himself, because they happen to him.

Existence as a transcendent elderly adult Being should be part of himself, it is not given by a process of aging as an isolated phenomenon, for it is the Being itself (being one in the world, that is, aging does not happen in isolation, but as part of himself) who seeks form the essence of his being. Isolated aging does not determine the plenitude, but the Being determines the plenitude of its aging. Understanding the discourse of the Being as an elderly adult, and aging as part of itself as a joint relationship that occurs on the basis of how that Being transcends itself as an elderly adult in the process; that same process is not separate, but it is part of itself. This stage of the elderly adult will be determined by a series of events that take place throughout his history, and that have given him a reason of meaning to be able to say that he has transcended to the idea of an aged Being, and now transcendent Being.

Then the Being that has aged is understood as a phenomenon, and if you want to separate the being which has experiences, this is the Being itself where it experiences fullness; therefore, as mentioned before, the being has possibilities, and said possibilities will determine its existence.

Transcendence is then the Being itself, since in being constituted in itself, it is already transcendent. Heidegger identifies transcendence as surpassing the Being, that which is dynamic, as it was previously marked; it is the Being itself in the world, being and existing, even when the Being has been understood, it has gone through the same understanding process ${ }^{(1,3)}$.

\section{TEMPORALITY AND HISTORICITY}

Particularizing that the Being is an elderly adult who asks himself about his own understanding by existing, that supreme understanding of the Being determines then that the Being is already transcendent. That elderly adult Being-There is there as a Being on a constant path; in a movement beyond itself, it is marked by temporality itself. This temporality is the Being-There united to presence and existence, it is not outside of the elderly adult Being, it is united to him ${ }^{(2)}$.

In the temporality that Heidegger emphasizes in becoming, there is the reason for the Being to be as it is, future and past at the same time as the present, so to speak; is the reason where the Being does and exists and that is not in the forgotten, but it remains. Temporality in the common sense would say that today is out of being, the present day is the time that will come to fade; for Heidegger, temporality is not an event in time, it is the Being. Temporality such as the Being is, in itself, already transcendence. That which the elderly adult Being is in that temporalization is the constant future of what has been, not in the sense of the future itself as it is understood, but it is the Being itself in the presence of the now, all that is temporality ${ }^{(1)}$.

The Being is shown as time, not in time, but as time itself and is temporalized in presence and action, and therefore appears visible in the world; it is the culminating reason that can be seen in its own history. This is not as the sum of time in a horizontal sense, but as the very creation of the Being in its comprehension as such, so that the historicity of the elderly adult Being can be analyzed not because it is in history itself, but because it exists in the same way that it is not an accumulation of Time. This is because if it accumulates, it talks about a plot of life (which constitutes historiography as a limitation of the study of the Being). When one goes into the form in which the Being walks as time itself, one can understand then that this sequence of experiences are no longer real in the moment of the here but until the Being has given a meaning in time; therefore, the Being is temporary.

So, man is not a sum of experiences that happen and die, this would mean separating him from linear time, outside the Being. As for Heidegger, time as something linear represented in history as past-present-future is an unlikely reason for the analysis of the Being. While it is true that experiences are cumulative, they are no more, as long as man gives them meaning ${ }^{(1)}$.

In the moment in which the Being is temporalized in the Having-Been, it is because it has reached transcendence, choosing the possibilities. Being temporality, the Being experiences having been, presently being, and becoming whole, when these three are manifested in Being as a Being. It is when its expression of illumination is visible, it is the opening for the Being against temporality in history, it is the total constitution of the Being, it is the Being that transcends.

It is the moment where the Being can find itself in time, again linking the three times as they are and that form its essence, the same essence represented in history. It is when the Being becomes visible as it is in the temporality of existing in the world. 
At this time, the analysis of temporality will be rooted in the internal and circular modes with the entity itself, it is the Being that at the moment examines the time-existence of itself where it finds the entity in the world. It is the moment of encounter and where the question that Heidegger sets is, "What is the way to transcend?"(1)

Then, the human being is the elderly adult Being in the world that presents itself to the phenomenon of aging, and which is already transcendence; that is, it is in the changes that it faces and chooses the possibility of being among the entities, or to understand itself as a plenitude, that allows him to continue to exist in the world and to enjoy said plenitude, the transcendence in Heidegger's view is the plenitude itself in the understanding of the Being.

What the Being is in temporality and historicity itself, is that which it has considered has allowed it, and which has passed as such in a linear time that is not of interest as of now, but rather the meaning of existence as such. The Being has not been prepared from birth to deal with aging, but those experiences to which it has given meaning are historically part of its temporality. The moment in which it is complete as transcendent in the stage of aging constitutes static temporality, because it has combined the ecstasy to be as it is. The question then posed by philosophy is: how is it that the elderly adult is transcendent?

Given this sense of the Being as a temporality in the world, then it is not understood that history is of entities, but the Being is historicity itself; not as an empty accumulation of existence in life, but as being integrated. This historicity of the Being in relation to temporality itself is the manifestation of the understanding and of the Being itself as transcendent, this being a path to understanding the Having-Been ${ }^{(1)}$.

The plot, to call it some way, results only in the ontological question about the Being itself, being then the historicity of the elderly adult determined by the way in which to be transcendent in the aging phenomenon, and given the existence in aging in the elderly adult Being, this is what gives way to reason again that the Being is one with the world and the phenomena. Aging does not appear first, followed by the Being, but the Being is in the aging; then the Being will be understood in its existence, not the existence in its aging.

The historicity then of the elderly adult Being belongs to itself, the very happening of the Being is its history, not in the sense as it is understood of accumulation, but as meaning it is also understanding as part of the Being. Existence as time of the elderly adult Being provides it with its very own possibility as a structural unit: the elderly adult Being understood as action, and as finite.

The elderly adult in transcendence is an historical Being from the sense of temporality, for understanding itself results in an always open path of the Having-Been. In other words, being able to interpret its "past", being a way of accessing what it has been, the way in which it has existed, being that found in a present of his knowledge in the "historical Being"(1).

And here, the two conductive threads of existence and metaphysics are tangled together, placing this question beyond the entity, being part of the nature of the Being, being a possibility as a decisive characteristic of the human being in which it is visualized and is sincere with himself, as well as asking about himself ${ }^{(1)}$.

It is the struggle of life that is based on the experiences of the Having-Been and that must be determined at a starting point; that point is not unique, but is continuous and flowing, by being in the world the Being faces multiple possibilities that it must resolve, manifested in its very existence.

That way of constituting the Being is existence itself, by which history makes the Being a historical Being, and focusing on that historical Being is how the phenomenon ends up unveiling. That phenomenon of the Being as transcendent is revealed for the same historical realization of the Being's experience ${ }^{(5)}$.

In this way, Heidegger's perspective on the reason of the Being as transcendence occurs in the perspective of its temporality, its history being important as a consequence of it being in the world, not in accumulation of experiences. Since that which is signified by the Being is then understood and manifested in the Having-Been, hence ontology itself is the question about the elderly adult Being in its context of transcendent versus its own temporality, which can be unified in practical terms because of its historical character.

\section{CONTRIBUTIONS OF HEIDEGGER'S CONCEPTS TO UNDERSTAND LIFE EXPERIENCES OF ELDERLY ADULTS: IMPLICATIONS FOR NURSING CARE}

For the discipline of nursing understood as care, it is necessary to approach the understanding of the elderly adult Being, since in reconciling the increase of the elderly at a global level, it becomes necessary to understand how that elderly adult has understood himself as a process of life itself (aging). The stage of old age is but a part of the temporality of the elderly adult Being as finitude in its existence, and the awaiting of death ${ }^{(6)}$.

Transcendence also denotes understanding, as we already mentioned throughout this reflection, but this understanding also denotes the ecstasy of the elderly adult Being. That ecstasy is the fullness of the temporality or the temporalities (having been, present, becoming) of the Being. The transcendent elderly adult Being is the comprehension of the fuller adult being manifested by its temporal existence, expressed in the very language of the Being, and that which is the same historical being that manifests itself as it is in the world ${ }^{(7)}$.

Martin Heidegger's concepts can help nursing understand complex phenomena situated in people's life experiences; when told, these experiences can be the access to the person, which can be understood and can relate to care. This is coupled with the increase of elderly adults in the world and the need to make them complete human beings, capable of living as full, autonomous, and self-giving "elderly adult Beings", facilitating the encounter with themselves, which is transcendence in a liberating expression ${ }^{(8)}$.

The configuration of the transcendental adult Being opens the way for a deep exploration of the elderly adult Being in the sense that being transcendent finds meaning in what he experiences day by day, even in this stage of aging. From this point of the lived present and towards the understanding of what has been, as this will be reflected in a full elderly adult Being and in a satisfactory inner relationship that allows it to 
better live its aging. Being configured as a historical Being, part of other Beings in the world, would allow nursing to conceptualize care under this philosophical perspective oriented to promote the transcendence of the Being.

\section{FINAL CONSIDERATIONS}

The transcendent elderly adult Being is one who has managed to understand itself in the world that surrounds it, configuring the image of a complete elderly adult Being fully understanding the meaning of lived experiences, that is, its temporality. The climax is the conjunction between having been and how it is now configured, for it can be deepened in it as a historical Being (historicity).

The study of Heidegger's philosophy and the adoption of his concepts for the nursing discipline opens the way to the very understanding of the human being, endows nursing with a broad perspective on who the Being is and how it is configured in the world. By accessing it, one could access the meanings of the experiences that form the Being until it reaches its own climax: its transcendence. This transcendence as understood and expressed in language can be a starting point for phenomenological exploration for the nursing discipline, since it is the supreme manifestation of the authenticity of the elderly adult.

\section{ACKNOWLEDGMENTS}

Acknowledgment to the Universidad Federal de Santa Catarina for the opportunity to carry out the Research Internship I that allowed this manuscript.

Acknowledgment to the Consejo Nacional de Ciencia y Tecnología (CONACYT, Mexico) for the funding to carry out the Research Internship I of the Doctoral Program in Nursing Sciences of the Universidad de Guanajuato.

\section{REFERENCES}

1. Heidegger M. El Ser y el Tempo. 7a ed. Petrópolis, RJ, Brasil: Vozes; 2012

2. Heidegger M. ¿Qué es metafísica? España: Alianza; 2006.

3. Heidegger M. Principios metafísicos de la lógica Madrid, España: Síntesis; 2014.

4. Muñoz PE. Trascendencia, mundo y libertad en el entorno de Ser y Tiempo de Martín Heidegger. Veritas [Internet]. 2015 [cited 2016 Apr 18];32:95-110. Available from: http://www.scielo.cl/pdf/veritas/n32/art05.pdf

5. Heidegger M. Marcas do Caminho. Petrópolis, RJ: Vozes: 2008.

6. Menezes TMO, Lopes Regina Lúcia Mendonça. Significados do vivido pela pessoa idosa longeva no processo de morte/morrer e luto. Ciênc Saúde Colet [Internet]. 2014 [cited 2016 Apr 18]; 19(8):3309-16. Available from: http://www.scielo.br/pdf/csc/ v19n8/1413-8123-csc-19-08-03309.pdf

7. Heidegger M. Sobre a essência da linguagem. Petrópolis, RJ: Vozes: 2015.

8. Menezes TMO, Lopes RLM. Significado do cuidado no idoso de 80 anos ou mais. Rev Eletr Enf [Internet]. 2012 [cited 2016 Apr 18];14(2):240-7. Available from: http://dx.doi.org/10.5216/ree.v14i2.13176 